\title{
Production of poly- $\beta$-hydroxybutyrate (PHB) and differentiation of putative Bacillus mutant strains by SDS-PAGE of total cell protein
}

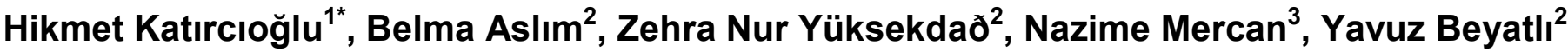 \\ $1^{*}$ Department of Biology Education, Gazi University, Ankara, Turkey \\ ${ }^{2}$ Department of Biology, Faculty of Science, Gazi University, Ankara, Turkey \\ ${ }^{3}$ Department of Biology, Faculty of Science, Pamukkale University, Denizli, Turkey
}

Accepted 16 May 2003

\begin{abstract}
In this study, the putative mutant strains of Bacillus megaterium $\mathrm{Y} 6, B$. subtilis K8, B. sphaericus X3 and $B$. firmus $G 2$ were studied for their poly- $\beta$-hydroxybutyrate (PHB) production capacities. Mutations were induced by using UV light, acriflavin and 5-bromourasil. Total cell proteins were extracted from 59 strains and compared using SDS-PAGE. For each strain, percentage yield of PHB according to cell dry weight was determined in a range of $1.46-63.45 \%$. PHB production of 8 mutant strains were found to increase in comparison with parental strains. However, no increase in PHB production of mutant strains of $B$. sphaericus $X 3$ was found. It was also determined that the protein profiles of the mutant strains with high PHB yield generally differed from the protein profiles of parental strains.
\end{abstract}

Key words: Bacillus, poly- $\beta$-hydroxybutyrate, PHB, total cell protein.

\section{INTRODUCTION}

The observation of Findlay and White (1983) that a strain of Bacillus megaterium accumulates a polymer called poly-beta-hydroxybutyrate (PHB) under nutrient stress led to investigations of the role of these polymers in the physiology of bacteria. The polymer was thought to be a simple polyester of beta-hydroxybutyrate monomers. A wide variety of prokaryotic organisms have been shown to accumulate this polymer, including numerous heterotrophic and autotrophic aerobic bacteria, photosynthetic anaerobic bacteria, gliding bacteria, Actinomycetes spp., cyanobacteria and recently, an anaerobic, fatty acid-oxidizing, gram-negative bacterium (Anderson and Dawes, 1990).

PHB is a biodegradable thermoplastic which can be extracted from a wide range of bacteria. The polymer which provides a reserve of carbon and energy, accumulates as intracellular granules. Reusch and Sadoff (1983) have shown that PHB is an important molecule on cytoplasm and cell walls. Bacillus species have been shown to accumulate PHB during the sporulation of bacterial growth. The PHB production capacities of bacteria have been investigated for possible application in industry (Lee, 1996; Hanzlikova et al., 1985; Nickerson et al., 1981; Lach et al., 1990). During the 1970's, in the aftermath of the first oil crisis, that the British chemical

"Corresponding author; Fax: (90) 312 2228483, E-mail: katircioglu@yahoo.com, hturk@gazi.edu.tr giant, Imperial Chemical Industries (ICl) began investigating the polymer-forming properties of bacteria. Alcaligenes lotus and $A$. eutrophus are presently utilized by $\mathrm{ICl}$ to produce a PHB-PHV copolymer under the trade name "Biopol" (Fiechter, 1990).

The presence of PHB has also been used in bacterial taxonomy for classification and identification (Dave et al., 1996). SDS-Page, based on total protein profiles, is used in bacterial taxonomy to the levels of the species and subspecies (Qhobela et al. 1991, Costas, 1990). Therefore, it can used to distinguish between mutants. The present study attempts to obtain mutant strains of Bacillus with high PHB yield and then compare the PHB production capacities with the total protein profiles.

\section{MATERIALS AND METHODS}

Reference organisms

B. megaterium $\mathrm{Y} 6, B$. subtilis $\mathrm{K} 8, B$. sphaericus $\mathrm{X} 3$ and $B$. firmus G2 strains were obtained from the stock collection of Biotechnology Laboratory at Gazi University. They were cultured in nutrient broth at $30^{\circ} \mathrm{C}$ for $24 \mathrm{~h}$ on a rotary shaker $(100 \mathrm{rpm})$.

\section{Mutant isolation}

Acriflavin (80-100 $\left.\mathrm{g} \mathrm{ml}^{-1}\right)$ and 5-bromourasil (80-180 $\left.\mu \mathrm{g} \mathrm{ml}^{-1}\right)$ were employed as chemical mutagens, while UV light $(254 \mathrm{~nm})$ was use as physical mutagen. In mutant isolations, concentrations which 
Table 1. PHB accumulation of parental and possible mutant Bacillus strains.

\begin{tabular}{|l|c|c|}
\hline \multicolumn{1}{|c|}{ Strain } & PHB $\left(\right.$ g. $\left.^{-1}\right)$ & Yields $^{*} \%$ \\
\hline Bacillus megaterium Y6 (parental) & $\mathbf{0 . 2 1} \pm \mathbf{0 . 0 2}$ & $\mathbf{4 8 . 1 3}$ \\
Bacillus megaterium A4 & $0.13 \pm 0.06$ & 63.02 \\
Bacillus megaterium A13 & $0.09 \pm 0.02$ & 63.45 \\
Bacillus megaterium A16 & $0.07 \pm 0.00$ & 54.62 \\
Bacillus subtilis K8 (parental) & $\mathbf{0 . 1 3} \pm \mathbf{0 . 0 1}$ & $\mathbf{3 2 . 5 0}$ \\
Bacillus subtilis B3 & $0.10 \pm 0.04$ & 33.71 \\
Bacillus subtilis B4 & $0.09 \pm 0.01$ & 41.86 \\
Bacillus subtilis B8 & $0.12 \pm 0.00$ & 61.32 \\
Bacillus firmus G2 (parental) & $\mathbf{0 . 1 0} \pm \mathbf{0 . 0 1}$ & $\mathbf{1 5 . 6 2}$ \\
Bacillus firmus D7 & $0.06 \pm 0.01$ & 34.12 \\
Bacillus firmus D11 & $0.03 \pm 0.01$ & 17.37 \\
\hline
\end{tabular}

${ }^{*}$ Calculated based on dry cell weight.

showed $99.99 \%$ lethality ratio were used. The possible mutants were isolated on nutrient agar with $1 \%$ Nile blue solution. Bacterial colonies then were stained by the Nile blue and examined under ultraviolet light $(235 \mathrm{~nm})$. PHB-positive colonies appeared orange wherease PHB negative colonies were white (Ostle and Holt, 1982).

\section{Determination of PHB}

Determination of the amount of PHB was performed chemically. Bacteria were grown on nutrient broth at $30^{\circ} \mathrm{C}$ for $48 \mathrm{~h}$ on a shaker. Suspensions of cultures were centrifuged at $6000 \times \mathrm{g}$ for $45 \mathrm{~min}$. Then the pellets were suspended in $5 \mathrm{ml}$ of sterile water and homogenized, using ultrasonic treatment $(2 \mathrm{~min})$. To $2 \mathrm{ml}$ of the cell suspension, $2 \mathrm{ml}$ of $2 \mathrm{~N} \mathrm{HCl}$ was added and heated to boiling temperature for $2 \mathrm{~h}$ in a water bath and the tubes were centrifuged at $6000 \mathrm{xg}$ for $20 \mathrm{~min}$. To obtain precipitate, $5 \mathrm{ml}$ of chloroform was added, and the tubes were left overnight at $28^{\circ} \mathrm{C}$ on a shaker at 150 $\mathrm{rpm}$. Then the contents of the test tubes were centrifuged at $6000 \mathrm{x}$ $\mathrm{g}$ for $20 \mathrm{~min}$, extracted with $0.1 \mathrm{ml}$ of chloroform, and was dried at $40^{\circ} \mathrm{C}$. $5 \mathrm{ml}$ of concentrated sulfuric acid was added, and the mixture was heated at $100^{\circ} \mathrm{C}$ in a water bath for 20 min. After cooling to $25^{\circ} \mathrm{C}$, the amount of $\mathrm{PHB}$ was determined spectrophotometrically at $235 \mathrm{~nm}$ (Bonartseva and Myschkina, 1985; Kuniko et al., 1988).

\section{SDS-PAGE of total cell proteins}

Cell-wall proteins were extracted as described in the method of Kishore et al. (1996). Electrophoresis of protein extracts was carried out using the discontinuous buffer system of Laemmli (1970). Gels were stained with Comassie Blue R250. Relative distances and similarities of the mutant strains to the parental strain were determined by using SDS-PAGE gel banding profiles and analyzed with SPSS 9.0 (for Windows) (Wolf and Rijini, 1993).

\section{RESULTS AND DISCUSSION}

Petroleum derived plastics are widely used in our daily lives, but they cause environmental pollution because they are persistent for hundred of years. Because of this, biodegradable polymer production (microbial termoplastics) has gained importance. Furthermore the continuous depletion of petroleum sources has placed more emphasis on the need for biodegradable microbial plastics. PHB is an important raw material for microbial plastics. Today, most research efforts in this field concentrate on the isolation of PHB producing microorganisms from different sources and improvement of PHB production abilities of microorganisms.

The present study was under taken by applying various mutagens to PHB-producing B. sphaericus X3 (36.36\%), B. subtilis K8 $(32.50 \%)$, B. megaterium Y6 $(48.13 \%)$ and $B$. firmus G2 $(15.62 \%)$ with the aim of obtaining mutants with higher PHB percentage yield. Dave et al. (1996) has reported 70 percent PHB of dry cell weight in optimum culture conditions for Bacillus sp. IPCB-403, while Findlay and White (1983) showed presence of PHB in $B$. megaterium using chromatographic method. Chen et al. (1991) also studied D(-)-3-hydroxyalcanoate in 11 different Bacillus sp. and found PHB consisting 50 percent of cell dry weight of the bacteria. In addition these investigators reported that PHB content changed depending on growth culture conditions. Our study showed PHB percentage yield of parental strains in some cases similar to and in others different from those reported by other workers. This may be due to different growth and culture conditions.

Eight of the 59 putative mutant strains obtained this study were found to show significantly higher PHB yield percentages (Table 1). Other strains showed PHB yields equal to or less than the parent strains. Other researchers have also reported PHB production changes in Bacillus mutant strains (Lach et al., 1990). Therefore mutations are considered of having the potential to change bacterial PHB content. In this study, a yield of $63.45 \%$ was found in one mutant strain $(B$. megaterium A13) while two others $(B$. subtilis $B 8, B$. firmus D7) have 
increased yield to about double that of parental strain. Today, some of the $A$. eutrophus strains used for commercial PHB production have cell dry weight of approximately 96\% PHB (Fiechter, 1990). Researchers have been focusing on increasing PHB percentage yields of other bacteria to this level using mutations.

Many researchers reported SDS-PAGE of total cell proteins as a powerful tool for the taxonomical discrimination of a great number of strains (Pot et al., 1992; Eaglesham et al., 1987). We have also employed total cell protein profile analysis (SDS-PAGE) of our parental and putative mutant strains to determine distances/similarities. The results are depicted in Table 2 as distance-similarity percent of mutant total protein profiles with parental proteins of $B$. megaterium $Y 6, B$. sphaericus $\mathrm{X} 3, B$. subtilis $\mathrm{K} 8$ and $B$. firmus $\mathrm{G} 2$. In general, we found mutant strain protein profiles to closely resemble those of parental strains.

Table 2. Similarities and distances of mutant strains from parental strains.

\begin{tabular}{|l|c|c|}
\hline \multicolumn{1}{|c|}{ Strains No } & Similarities \% & Distances \% \\
\hline Bacillus megaterium A4 & 78 & 22 \\
Bacillus megaterium A13 & 40 & 60 \\
Bacillus megaterium A16 & 86 & 14 \\
Bacillus subtilis B3 & 88 & 12 \\
Bacillus subtilis B4 & 93 & 7 \\
Bacillus subtilis B8 & 67 & 33 \\
Bacillus firmus D7 & 33 & 67 \\
Bacillus firmus D11 & 73 & 27 \\
\hline
\end{tabular}

In a similar experiment, Basha and Ulaganathan (2002) applied the chemical mutagen, nitrosoguanidine to Bacillus sp. BC121 and the probable mutant strain obtained Bacillus sp. BC121M protein extract to showed a missing parental $25 \mathrm{kD}$ band when compared using SDS-PAGE. In addition they showed disappearance of a certain previously present band. Saxena et al. (2002), also obtained probable UV tolerant mutant from $B$. thuringiensis subsp. kurstaki and used total protein SDSPAGE method to determine the differences in banding. They reported loss of $71 \mathrm{kD}$ band in the mutant strain.

In this study, it was determined that protein profiles of the mutant strains with high PHB yield was generally different from the protein profiles of parental strains. Here we have shown that it is possible to increase PHB yield by using mutagenic treatments. Furthermore, it is also possible to determine the effect of mutation using the protein profiles.

\section{REFERENCES}

Anderson AJ, Dawes EA (1990). Occurrence, metabolism, metabolic role and industrial uses of bacterial polyhydroxyalkanoates. Microbiol. Rev. 54: 450-472.

Basha S, Ulaganathan K (2002). Antagonism of Bacillus species (strain BC121) towards Curvularia lunata. Current Science 82:1457-1463.

Bonartseva GA, Myschkina VI (1985). Fluorescence intenstiy of strains nodule bacteria (Rhizobium meliloti,. phaseoli) differing in activity, grown in the presence of the lipophilic vital stain phosphine $3 R$. Mikrobiologiia 54: 535-541.

Chen G, König K, Lafferty RM (1991). Occurrence of poly-D(-)-3hydroxyalkanoates in the genus Bacillus. FEMS Microb. Lett. 84:173176.

Costas M (1990). Numerical analysis of sodium dodecyl sulphatepolyacrylamide gel electrophoretic protein patterns for the classification, identification and typing of medically important bacteria. Electrophoresis 11: 382-391.

Dave H, Ramakrishna C, Desai JD (1996). Production of PHB by petrochemical activated sludge and Bacillus sp. IPCB-403. Ind. J. Exp. Biol. 34: 216-219.

Eaglesham ARJ, Stowers MD, Maina ML, Goldman BJ, Sinclair MJ, Ayanaba A (1987). Physiological and biochemical aspects of diversity of Bradyrhizobium sp. (Vigna) from three west African soils. Biol. Biochem. 19: 575-581.

Fiechter A (1990). Plastics from bacteria and for bacteria: Poly (betahydroxyalkanoates) as natural, Biocompatible and Biodegradable Polyesters. Springer-Verlag, New York, pp. 77-93.

Finlay RH, White DC (1983). Polymeric beta-hydroxyalkanoates from environmental samples and Bacillus megaterium. Appl. Environ. Microbiol. 45: 71-78.

Hanzlikova A, Jandera A, Kunc F (1985). Formation of poly-3hydroxybutyrates by a soil microbial community in the soil. Folia Microbiol. 30: 58-64.

Kishore L, Natarajan K, Babu LR (1996). Total soluble protein and membrane lipopolysaccharide profiles in differentiating Rhizobium isolates. Microbios 86: 143-156.

Kuniko M, Nakamura Y, Doi Y (1988). New bacterial copolyesters produced in Alcaligenes eutrophus from organic acids. Polymer Commun. 29: 174-176.

Lach DA, Sharma VK, Vary PS (1990). Isolation and characterization of unique division mutant of Bacillus megaterium. J. Gen. Microbiol. 136: $545-553$.

Laemmli UK (1970). Cleavage of structural proteins during the assambly of the head of bacteriophage T4. Nature (London) 227: 680-685.

Lee SY (1996). Bacterial polyhydroxyalkanoates. Biotechnol. Bioeng. 49: 1-14.

Nickerson KW, Zarnick WJ, Kramer VC (1981). Poly- $\beta$-hydroxbutyrate parasporal bodies in Bacillus thuringiensis. FEMS Microbiol. Lett. 12: 327-331.

Ostle A, Holt JG (1982). Nile Blue A as a fluorescent stain for Poly- $\beta$ hydroxybutyrate, Appl. Environ. Microbiol. 2: 238-241.

Pot B, Vandamme P, Kersters K (1992). Analysis of electrophoretic whole organism protein fingerprint. In: Chemical method in bacterial systematics, A.G. O Donnel C: J. Wiley \& Sons, pp. 85-96.

Qhobela M, Leach JE, Claflin LE, Pearson DL (1991). Characterisation of starins of Xanthomonas campestris pv. holcicola by PAGE of membrane proteins and by REA and RFLP analysis of genomic DNA. Plant Disease 75: 32-36.

Reusch RN, Sadoff HL (1983). D-(-)-Poly- $\beta$-hydroxybutyratein membranes of genetically component bacteria. J. Bacteriol. 156: 778788

Saxena D, Ben-Dov E, Manasherob R, Barak Z, Boussiba S, Zaritsky A (2002). A UV tolerant mutant of Bacillus thuringiensis subsp. kurstaki producing melanin. Curr. Microbiol. 44:25- 30.

Wolff K, Peters-van Rijn J (1993). Rapid detection of genetic variability in chrysanthemum (Dendranthema grandiflora Tzvelev) using random primers. Heredity 71 : 335-341. 